\title{
Racial Politics and Hausa-Fulani Dominant Identity in Colonial and Post-colonial Northern Nigeria
}

\author{
Erima Comfort Ugbem ${ }^{1}$ \\ Ayokunle Olumuyiwa Omobowale ${ }^{2}$ \\ Akinpelu Olanrewaju Olutayo
}

\author{
Department of Sociology 1 \\ Benue State University \\ Markurdi, Nigeria \\ Department of Sociology ${ }^{2}$ \\ University of Ibadan, Nigeria
}

\begin{abstract}
The paper examined racial politics and identity contests in Northern Nigeria. The paper specifically traced the trajectory of racial politics and examined the dynamics of identity construction and contests in Northern Nigeria. An essentially qualitative method of data collection comprising primary data generated through in-depth interviews and secondary data generated through archival records were used. These were then subjected to content and descriptive analyses. Findings from the study revealed that racial politics originated during colonial rule with the British supposedly claiming gene/biological affinity of the Hausa-Fulani as with the Caucasoid groups of Eurasia. The Hausa-Fulani were consequently designated as the civilized group and super-imposed over minority groups that were classified as pagans. About six decades after colonial rule, Hausa-Fulani dominance remains a social reality in spite of identity contests and recreation by the minority groups of Northern Nigeria. Starting with the creation of the Middle Belt identity in the late 1950s, the constituent groups within the Middle Belt have consequently recreated other ethnic identities within Northern Nigeria. Notwithstanding, Hausa-Fulani remains the dominant group in Northern Nigeria socio-political structure.
\end{abstract}

Keywords: Colonialism, racial politics, Hausa-Fulani, identity, Northern Nigeria

\section{Introduction}

Research in the area of genetics has had far reaching implications for individual and group conceptions of racial and ethnic identity in recent times. This is because the body of knowledge created by the study of genetics such as inherited traits, illness, intelligence and more recently the human genome project has been subjected to varying interpretations, misinterpretations as well as debates (Carter and Dyson, 2011; Smart et al., 2008; Condit et al., 2004; Santos and Maio, 2004). One fulcrum on which the debate is hinged is on the epistemological status of race. There appears to be a division between scholars on race as a socio-political construct and race as a natural or biological reality (Billinger, 2007; Condit et al., 2004; Modood et al., 2002; Brown, 1986). While this remains unresolved, some have advocated the use of genetic 
markers to differentiate between groups in the society thereby resulting in an emergent trend where particular races are seen as superior to others on the basis of the possession of superior "genetic" qualities (Hacking, 2005; Bamshad et al., 2003; Sarich \& Miele, 2004; Rosenberg et al., 2002; Schwartz, 2001). This trend links race with biology, essentializes identity, naturalizes differential treatment and promotes inequality. The history of many countries of the Third World are replete with such situations where genetic explanations have been used to designate some groups as genetically and constitutionally inferior to others thereby justifying oppression and discrimination (MacEachern, 2007; Duster, 2006; Duster, 2003; Sarich \& Miele, 2004; Herrnstien and Murray, 1994; Jensen, 1968). This paper is focused on the colonial creation of a superior identity for the Fulani of Northern Nigeria using genetics and the implications it has had for the identity of other ethnic groups as well as the social relations this had generated within the Northern region of Nigeria and Nigeria at large.

The Nigerian state as it exists today was historically a plethora of ethnic/cultural groups and/or nations, which existed independent of one another (Alubo, 2004; Gana, 2002). These groups were selectively and differentially colonized by the British resulting in the creation of a Northern and a Southern Protectorate. These Protectorates existed independently and were administered with different laws though under the British. Within these Protectorates all the ethnic nations were subsumed under a dominant identity by the British using perceived cultural superiority as a basis. In the Northern Protectorate over a hundred ethnic nations were subsumed under the Caliphate and Emirate system of the Hausa-Fulani. The Southern Protectorate was divided into two regions; the Eastern Region and the Western Region. The Igbo were the dominant group in the Eastern Region while the Yoruba assumed the dominant stature in The Western Region. These colonial protectorates existed independently until they were amalgamated in 1914 to form Nigeria. Nigeria thus became a country comprising many ethnic nations subsumed under three dominant identities of the Hausa-Fulani, in the Northern Region, the Igbo in the Eastern Region and the Yoruba in the Western Region (Mustapha, 2006; Alubo, 2006).

The perceived superior genetics of the Fulani has been widely researched upon by scholars. MacEachern (2007) links Fulani superiority to a traditional conception of race that distinguishes between Negroid and Caucasoid people, history and culture. According to MacEachem earlier research historically associates the Mediterranean basin along with the cultural advances that took place there in antiquity with Caucasoid population, considering them to be well beyond the capabilities of Africans living south of the Sahara. This notion invariably places the boundary between Africa and the rest of the world somewhere along the fringes of the desert. He further posits that Fulbe, Haratin, Teda/Daza are examples of racially mixed groups or earlier remnants of racially mixed groups and/or remnants of earlier people over run or subjugated by white immigrants from the North over the last few thousand years. Others 
scholars have suggested a possible link between the Fulani and the Berber, the gypsies, Arabia and Eurasia (Winters, 2011; Hampshire et al., 2001; Burdon, 1904), accounting for Fulani non-Negroid links and possibly genetic superiority.

The Fulani migrated to pre-colonial Hausa communities about the 16th Century (Bourdon, 1904; Chard, 1906). Through the Uthman Dan Fodio Jihad, the Fulani eventually overthrew Hausa Habe political kingship (Burdon, 1904). The Fulani political leader thus created a theocracy with unitary headquarters headed by the Sultan at Sokoto while Emirs were installed in other towns (Waldman, 1965). The Hausa talakawa (commoners) were formed the fulcrum of the Fulani army. Hausa population was in the majority and of course, their support for the Fulani aristocracy sustained the Fulani leadership in power. United by religion and the supposed corruption, idolatry and debauchery of the Habe leadership, the Hausa and Fulani integrated into a uniform theocratic kingdom. The Fulani leadership further sustained their political base among the Hausa majority through intermarriage and the adoption of the Hausa language and culture. The Fulani, however, did not dispense their identity, language and culture.

In all, the Hausa populace remained subjects with only a few privileged serving as chiefs and court, administrative and palace officials. (Bourdon, 1904). This was the situation up to the point the British conquered the HausaFulani and the whole of Northern Nigeria as from the late 19th Century (Chard, 1906). Over the years, Northern Nigeria has experienced of identity constructions, contests and identity related conflict that have reconfigured social relations from that of mutual peaceful existence to mutual suspicion and violent conflict. This situation can possibly be traced to racial politics by the British colonialists. The paper traces the trajectory of racial politics in Northern Nigeria and examines the ensuing identity constructions and contests in Northern Nigeria.

\section{Methods}

An essentially qualitative method of data collection was adopted for the study. Both primary and secondary sources of data were used. Primary data was collected through in-depth interviews. In-depth interviews were conducted with two historians, three political office holders, five retired government officers, five leaders of ethnic associations, and five traditional rulers. Secondary data was generated from archival resources. A total of 20 IDIs were conducted. Archival research was conducted at the National Archives Kaduna and the National Archives Ibadan where extant colonial records including intelligence reports, Annual records, Minutes of meetings as well as other colonial correspondences were consulted. This study is actually part of a larger study on identity construction dynamics among ethnic groups in Benue state, NorthCentral Nigeria. Both the primary and secondary data were then subjected to content and descriptive analyses. 


\section{Colonialism and Paganization}

Aside the Hausa-Fulani, the pre-colonial Northern region consisted of other groups, which were independent of the Hausa-Fulani political arrangement. There were over a hundred socio-cultural and distinctively linguistic groups who were largely animists with varying religions. The British brought these groups under Hausa-Fulani domination at the commencement of colonial rule. The Hausa occupied the Northern half of Northern Nigeria while the southern half was occupied by over a hundred other ethnic groups who had distinct cultural practices, language and identities. The Hausa existed in various groups and traced their origins to different progenitors. For instance the Kanuri in Borno trace their origin to Sef, a progenitor or ancestor, who named the whole of the empire after himself- sefewa- the people of Sef. Other Hausas west of Bornu trace their origin to one Bayajida who founded the state of Daura from which grew the seven Hausa states of Daura, Zaria, Gobir, Kastina, Rano and Biram (Dudley, 1968) The identity of these ethnic groups revolved around the progenitors. Though these identities existed, the introduction of Islam and the consequent conquest by the Fulani brought these groups under a caliphate system and centralized the governance under a Sultan who resided in Sokoto.

The ethnic groups in the southern half of the Northern region also traced their origins to various progenitors. For instance, the Tiv trace their origin to Takuruku whom they regard as the biblical Adam (Hembe, 2005), the Idoma trace their origin to Apa and regard themselves as the children of one Idu, (Benue Province Annual Report, 1931) and the Igede trace their origins to one Agba of Sabon Gida Ora in present day Edo State (Odey, 1980). These ethnic groups along with their myth of origin had their indigenous forms of religion. All these in addition to their cultural practices and beliefs created distinct identities for them. Though these existed, many of the ethnic groups of Idoma, Igala, Jukun, and Etulo make reference to a Kwararafa kingdom which existed in the-16th century but disintegrated as a result of identity contests and raids from the Hausa-Fulani.

Colonial occupation in the Northern Nigeria was not a smooth process as the colonialist adopted various measures to bring the cultural/ethnic groups/nations under colonial control. Aside the adoption of the indirect rule system (Dudley, 1968). British colonialists contracted anthropologists and missionaries who researched and wrote intelligence reports on the various ethnic groups in Northern Nigeria. Claiming empirical findings, the colonialists broadly grouped the people of Northern into two namely: the Hausa- Fulani and the pagans. According to Burdon (1904: 636-637)

...as with climate and nature, so with man. From the lightcoloured, straight-featured Fulani, one passes through many gradations to the typical Negro of the coast. The characters of the two types are as different as their looks. Ethnology teaches us the effect of environment on race and it is therefore easy to understand why the forest and swamp-dwellers of the south should be of a lower type than the in-habitants of the open 
northern plains. But history tells of the southward movement of superior races from the north, and it seems probable that this pressure has forced coastward inferior aboriginal plain-dwellers... England pictures West Africa as peopled by "niggers" the type of negro whom it helped to degrade by the over-sea slave trade; for the Mohammedan states of Northern Nigeria this picture does not hold good... Not only did this tract escape this product of European civilization, but we have there an entirely different type, a higher race, one from which great things may be hoped in the future, and which will assuredly make its mark in the collection of races that constitute the British Empire.

The colonialists saw the Fulani as a superior race to the rest of the inhabitants of the Northern Protectorates who were the pagans. British colonial officials believed Fulani possess special qualities that were regarded as higher than the other Negroid or pagan races. The colonialist in essence used skin colour to create a superior identity for the Hausa-Fulani and an inferior identity for the other ethnic groups within the region. This categorization is of course associated with racists conceptions which views the white race as the superior race just on the basis of skin colour. In fact, some genetic based studies ascribe superior intelligence and particular diseases to some races and have even advocated for differential policies with regards to treatment of these races (Jensen, 1968; Jensen, 1965; Erlenmeyer-kimling and Javik, 1963; Eells et al., 1951). The colonialists obviously looked for people who had similar physical attributes to the West. They probably felt more at home working with people who had something close to the white skin.

Taking these submissions as colonial official policy, British colonial officials took Hausa and the Fulani on the basis of genetic cum physical attributes as superior to the other Negroid tribes in Northern Nigeria. These Negroid tribes were to assume a new identity under colonial administration. They were referred to as the "pagans". Negroid groups assumed "pagan" identity due to their classification as savage idolaters as against the Muslim monotheist Hausa-Fulani (Orr, 1965; Northern Provinces Annual Reports, 1920, 1926). This distinction is captured by Meek (1921: 5) thus;

If we consider Islam as a political, social and economic factor, the case is very different. Islam has brought civilization to the barbarous tribes. It has converted isolated pagan groups to nations: it has made commerce with the outside world possible and has been the chief instrument in the development of commercial instinct which has made the Hausa, Nupe, Yoruba and the Beri beri famous. It has broadened the outlook and raised the standard of living by creating a social atmosphere and has conferred on its followers dignity, self-respect and respect for others. The intellectual and political superiority of the Muslim communities is chiefly due to their religion. Islam introduced the 
art of reading and writing and the prohibition of the use of alcohol, of cannibalism, blood, revenge and other barbarous practices; it has enabled the Sudanese Negro to become a citizen of the world... it is largely due to Islam that the numbers of tribes are now before our eyes, forming themselves into nations; and it is largely due to Islam that the indirect government by great Britain is made possible...

On the other hand, so called pagan groups were described thus:

Farther in the interior, in the hills that extend from west to east at a distance of about a hundred miles from the north bank of the river, pagan tribes of much lower type are to be found. Many are cannibal, and in many no clothing whatever is worn by either sex. Here we begin to get an idea of what primitive man was like. Absolute insecurity is the day-to-day reality, which of necessity dominates the actions and habits of the people. There is practically no cohesion, no organisation. Villages of little beehive-shaped mud or grass huts are perched on seemingly inaccessible heights, or cunningly hidden in a maze of dense tropical vegetation. At early dawn the men, carrying their bows and arrows - from which it is never safe for them to be partedsally out to the fields at the foot of their fastnesses to cultivate their crops, whilst the women pick their way down to the springs to fill the earthenware water pots which they carry on their heads. Towards sunset the men may be seen making their way back up the steep rocks to their homes on the summit, with their bows still slung over their shoulders, and carrying in their hands the hoes which form their sole implements of agriculture (Orr, 1965: 69).

The other groups who did not practice Islam were regarded as barbarous tribes and pagans. The pagan way of life was barbaric in comparison to Islam, which was a civilizing religion. The pagan was also regarded as timid and fearful while the Muslims were regarded as settled and civilized. The designation "pagan" inherently had a connotation of cultural inferiority to the Hausa-Fulani dominant identity. The colonialists further classified pagans on the basis of their social organization. Pagans were classified as thus: Sophisticated pagans which were further divided into settled and unsettled pagans and the unsophisticated pagans which were further divided into timid and savage pagans (Record of Proceedings of the Education Department Conference, 1927; Pagan Administration, 1924; Alubo, 2006). In many instances the other ethnic groups were described in derogatory terms. For instance a submission in a colonial document claimed that: The Idoma are only emerging from a state of primitive savagery (Benue Province Annual Report, 1932: 32). 
Also

Economically as well as culturally the Idoma division is the most backward area and there the scarcity of currency is the greatest. They are a serious embarrassment to the administration (Benue Province Annual Report, 1933: 1175).

\section{Likewise}

The south west in the Idoma division containing the IIede and the Idoma tribes, the later has hardly emerged from a state of primitive savagery into which it occasionally relapses (Benue Province Annual Report, 1934: 1168).

Again

... contains pagans and sections of tribes in varying stages of culture ranging from the primitive Idoma who have recently abandoned head hunting and the equally primitive Munshi [Tiv] .... (Benue Province Annual Report, 1931: 709).

The colonialist obviously saw nothing good in the pagans and as such they took every opportunity available to compare the pagans with the Hausa and Fulani and extol the virtues of the latter. Derogatory terms were used to further communicate and entrench the inferior identity that had been created for the pagans.

The British fancied the Fulani centralized political and social organization, very unlike that of the pagan tribes who had un-centralized, and sometimes segmented social systems. The colonialist preferred the Hausa- Fulani centralized system where they had one representative controlling the whole of the tribe unlike the un-centralized system among the pagan tribes. The HausaFulani all owed allegiance to the Sultan of Sokoto who is regarded as both spiritual and political head. The Hausa-Fulani centralized political organization was strategic to the British indirect rule system. Thus, the British then established relations with the caliphate and proceeded to impose the HausaFulani system of social organization on the other ethnic groups.

It is important to note that while the British were creating identities for the ethnic groups, the Hausa and Fulani had also created an identity for these ethnic groups. The Hausa regard themselves as having originated from the seven Hausa states popularly regarded as Hausa bakwai while the other ethnic groups were regarded as belonging to the banza bakwai meaning the seven illegitimate states or the bastard seven. Hausa bakwai and banza bakwai is usually used by the Hausa to differentiate themselves from the other ethnic groups which they regard as illegitimate or bastard Hausa states. The identity of banza can be explained using the analogy of a child who is regarded as illegitimate. In African cultures a bastard or an illegitimate child is not usually accepted as the child was not born within the confines of a family. Furthermore such a child is not entitled to inheritance. "This child is basically neither here 
nor there". Such children are not respected or appreciated. Invariably the identity of banza inherently points to the pagans as illegitimate. It also means they are not entitled to enjoy certain rights and privileges. The pagans had various identities to contend with; first banza identity created by the HausaFulani and later the pagan cum inferior identity created by the British colonial officials.

The adoption and imposition of the Hausa-Fulani system of social organization implied the imposition of a Hausa - Fulani identity on the other linguistic groups in the Northern Region. Emirates with Hausa Fulani Emirs were imposed on the other linguistic groups. In areas where there were no emirs, chiefdoms with Hausa or Fulani or Muslim kings known as Sarki were created. A system of taxation, which was historically part of the Hausa-Fulani way of life but alien to the other linguistic groups was imposed throughout the Northern region. The other linguistic groups were reorganised in provinces for the purpose of paying tax. This organization was such that linguistic groups were lumped together in provinces under a Hausa-Fulani king, chief or Emir for the purpose of tax collection. The colonialists using gene politics created an inferior- superior social structure arrangement within the Northern Region that was to later play out in form of identity contests as well as violent conflicts. It is important to note that Hausa became the formal language of communication in the Northern Region. The other linguistic groups were forced to adopt Hausa to communicate.

Where ever the British colonialist went the Hausas went with them as interpreters, messengers and security guards. Language is a significant aspect of identity of a people as it provided one with a way of thinking, seeing and doing. It also places one within a social structure and provides a way of making meaning of everyday life and experiences. Adopting Hausa language meant adopting a Hausa social identity; way of thinking, seeing and intimately being. The linguistics groups as a result of gene politics were forced to adopt an identity that was alien to them. The colonialists through gene politics imposed a social structure and culture on the other non Hausa-Fulani linguistic groups in the Northern Region.

This identity created by the British did not go without contests and resistance from the people. In 1906 there was a contest between the Tiv and the colonialists at Abinsi town which was the headquarters of the Munshi province (Makar, 1995). The contest started initially as a quarrel between a Jukun man and a Hausa female trader. It later escalated into a full-scale fight where the Jukuns were beaten to the event that one ran to the nearby Tiv settlement to seek for help. The Tiv came out in their numbers, fought with the Hausa, killing some, injuring others and even pushing some forcefully into the river. They also vandalized the warehouse belonging to the British. A British force comprising 38 officers Non Commissioned Officers (NCOS), 600 soldiers supported by artillery and maxim guns and 1000 carriers drove the Tiv away from Abinsi and in the process over 100 Tiv were killed (Makar, 1994). A Munshi (Tiv) expedition was subsequently organized but had to be cut short 
because of the satiru rising in Sokoto (Munshi expedition, 1906; Makar, 1994). Also in 1928 there was the Ogbiloko uprising among the Igede in the Idoma division of the Benue province. Ogbiloko was historically a traditional medicine man who was respected by the Igede and was believed to possess mystical powers. Ogbiloko mobilized the natives of Igede and promised them immunity from the British weapons. Ogbiloko mobilized the igede to resist the imposition of tax by attacking the divisional officer, sacking the district headquarters of the colonialist of igede and Ito and destroying the Hausa settlement at Oju. The British organized a patrol, which lasted for a year. A lot of people were killed as well as villages destroyed in the course of the patrol. Ogbiloko was finally captured and killed in April 1929 (Benue Province Annual Report, 1928; Benue Province Annual Report, 1929).

A Nyambuan movement- rotten meat movement also emerged among the Tiv in 1939. This movement was actually directed against the elders whom they believed had been bought over by the Hausa- Fulani. It was directed at the elders because of power of magic, which they were believed to posses. The movement held out promises of eternal life to its members as well as complete immunity from witchcraft. This movement threatened the authority of the administration as the movement took over the powers of the Alkali courts that had been provided by the colonialists. This movement was repressed and put to an end through military patrols and a publication of an order in council prohibiting the invocation of the Nyambuan juju and conferring powers upon the native courts to try cases arising out of the practice of Nyambuan (Benue Province Annual Reports, 1939).

Again in 1947, the Tiv in Makurdi rioted in protest of the imposition of a Sarkin (meaning king in Hausa language) Makurdi on them. The Sarkin Makurdi Dan Afoda was a Yoruba Muslim who was historically an interpreter for the British colonialist. At his death in 1947, plans were made for his son to succeed him. This was violently resisted by the Tiv people. The colonialists responded by creating a town council, which comprised more of non-Tiv members (Benue Province Annual Records, 1947). Many of the ethnic groups remained silent until the eve of independence in 1960 . Party politics were then introduced in the 1950s. Regional political parties were formed. The Action Group (AG) was dominant in the Western Region while the National Council of Nigeria and the Cameroons (NCNC) was dominant in the Eastern Region. The Hausa-Fulani converted a cultural organization known as Jamiyyar Mutanem Arewa (the gathering or the collection of the Arewa people), into the National Peoples Congress (NPC).

The NPC was the dominant party in Northern Nigeria. All the other linguistic groups in response to this created a regional identity known as the "Middle Belt" to contest the Hausa-Fulani hegemony. A political party known as the United Middle Belt Congress (UMBC) was subsequently formed (Mustapha 2002). This was greeted with repression from the NPC dominated government of the Northern Region. The repression consequently led to the Tiv riots of 1957 (Hembe, 2005). Apart from the Tiv riots, there was a strong 
agitation for the creation of a Middle Belt State from the Northern Region. This led to the setting up of the Willink Minority Commission, which was then saddled with the responsibility of looking into the fears of the minority groups and suggesting ways to allay these fears. This commission came to the conclusion that the creation of a separate state would not put to rest the fears that had been expressed so they recommended instead that the fundamental rights of individuals stated in the constitution be respected (Willink Commission Report, 1958). The ethnic groups were forced to maintain status quo until independence in 1960.

\section{Post-colonial identity Contests and Reconstructions}

Though independence was granted to Nigeria in 1960, the British colonial structure still remained intact in the Northern Region. The superior genetic identity created by the British played out in the area of political participation and appointments and elections. In the Northern region, the civil service, native police and all other government agencies were dominated and controlled by the Hausa-Fulani to the exclusion of the other linguistic groups. Before independence these groups had formed tribal unions, which came under a Middle-Belt identity, which culminated in the formation of the United MiddleBelt Congress (UMBC). The creation of the Middle belt identity was a process of reconstructing their identity from the former inferior identity that had been imposed on them by the British colonialists cum Hausa-Fulani.

After independence in 1960, the other linguistic groups began to assert the more the Middle Belt identity that had been created in the 1950s. The UMBC in the Tiv area were able to contest and win elections into the Northern House of Assembly. The Hausa-Fulani NPC dominated government responded by repressing the people. Members of UMBC in the Tiv area were beaten, others were arrested and imprisoned (Hembe, 2003; Dudley, 1968). UMBC members were not given permits to hold meetings or rallies. This subsequently led to a riot in the Tiv area in 1960 (Hembe, 2003; Makar, 1994). In 1964 there was a threat of secession where Isaac Shahu (A Tiv) of the UMBC declared on the floor of the Northern House of Assembly that the Tiv felt unwanted and since they were up 1,000,000 (bigger than some African countries like Gambia and Mauritania) and they would pull out of Nigeria and become a country of their own (Mustapha, 2002). This assertion set a stage for what was to be regarded the worst Tiv riot in the history of Northern Nigeria.

Here reconstruction of identity from the hitherto inferior imposed by the British through gene politics had assumed a violent dimension. Lots of lives and properties were lost and a commission of enquiry was subsequently set up to look into the causes of the riot. In 1966 the armed forces took over the rulership of Nigeria through a coup and counter coup where top political leaders across the three regions were killed. From then on till 1999 Nigeria remained under the rulership of the military, which was dominated and controlled by the Hausa-Fulani. During the military era, the linguistic groups were largely silent until except for some pockets of minority resistance against 
the Hausa-Fulani domination in the late 1980s (especially the Zango-Kataf crisis). From 1999 when Nigeria returned to civil rule, there has been series of identity related violent clashes in the Northern region. Besides, the minority groups hitherto united under the banner of the Middle Belt are championing independent identities within the North-Central Region.

One of the strategies the military regimes utilized to give a reflection of independent identity to minorities under the Hausa-Fulani hegemony was the creation of states. This in a way took care of the minority agitations for a state of their own. Inherent in this state creation was a situation where some of the groups who were minorities under the Hausa-Fulani domination, and had accepted the Middle Belt identity umbrella as a leeway from Hausa Fulani domination became the majority ethnic groups in the new states (in terms of population). Many of these groups who were the majority transferred the dominance subjection social structure created by the British colonialists cum Hausa-Fulani to their states. A new host of exclusion/inclusion structures emerged though minimal as there were silent contests for dominance among the ethnic groups which had hitherto created a Middle Belt identity to contest their non-inclusion in the Northern Region political process and structure.

The transition to civil rule in 1999 saw the ethnic groups who had jointly created the Middle Belt identity engage one another in identity contests assuming violent dimensions. These linguistic groups in the phase of the free atmosphere occasioned by the civilian rule began to reconstruct their identities from the Middle Belt to distinct ethnic identities. Within some of the states were new "gene" politics bordering on "indigeneship", "settler" and the "stranger". The indigenes are those with biological and aboriginal affinity (origin) with the community. Settlers are the descendants of migrants who may have settled in the communities over the centuries and have lost contact with their original communities. Lastly the strangers are Nigerians who have migrated just recently for economic reasons but could still trace their roots. Of all the "new" identities, only the indigenes are entitled to states resources while the settlers and strangers are excluded.

Lately, the politics of inclusion and exclusion in access to resources, resulting from colonial gene politics has resulted in the new identity contests and recreation in contemporary democratic process. For example violent intertribal wars have occurred among the Tiv/Jukun, Tiv/Alago. Tiv/Idoma, Tiv/Igede etc. (Alubo, 2004; Alubo, 2006; Best, 2006); all in the quest to accentuate and affirm distinct identities. It is noteworthy to state that these contending groups were the same groups that had hitherto united under the Middle Belt umbrella in the pre-democracy years. Interviewee posits:

The Igede were no so active in the Middle Belt movement. It looked more like a Tiv idea. But I believe the movement broke down because of suspicions, selfishness and the fact that we all have our various histories and cultural practices to protect. (Female IDI/ Women Leader /Oju Community/29th June, 2011) 
Another interviewee states:

... you see, not all the ethnic groups in the middle belt were actively involved in the agitation for the middle belt. With the low level of development and education then, many people did not know what was happening. Many of them did not really know what the movement was all about. The idea of the middle belt failed because of suspicion and the fact that people wanted to create space for themselves. This space is both political and physical like land. That is why you will notice that most of the conflicts revolved around land and politics. You see the colonialists lumped ethnic groups with various histories and cultural practices together and these groups were forced to accept the identities that were not theirs. The middle belt agenda was just an agenda of convenience to fight the Hausa-Fulani. Many of the ethnic groups took advantage of the free atmosphere of the civilian regime to express their grievances. (Male IDI/ Historian/Makurdi /27th May 2011)

A traditional title-holder at Markurdi further stated:

Some of our traditional leaders were not sincere. Some of them were against the middle belt idea because they were benefitting from the colonialist. So while some were agitating for it others were working against it. There was no real unity among the ethnic groups. That is why it was so easy to begin to fight among ourselves in the Middle Belt... there are many languages and cultural practices in the middle belt. All of these were suppressed as a result of colonial rule. So the civilian rule was just an opportunity for expression. (Male IDI/ Traditional Title Holder/ Makurdi/ 12th June 2011)

Still, another interviewee affirmed that:

Even though the Middle Belt movement existed, some of us were still minority within the minority ... the Tiv Jukun crisis that took place in 1995 actually made people to know that an ethnic group like Jukun existed within Benue state. The crisis brought out Jukun identity. (Male IDI/ Leader, Ethnic Association /Abinsi/29th April 2011)

The superior political identity created by the British eventually resulted in ethnic conflict conflicts between the Hausa-Fulani and the minority groups. Just like the British created an identity of convenience to enhance the achievement of their goals, the minority ethnic groups created a social identity named The United Middle Belt Congress comprising of groups that had been designated as pagans) as a tool to contest the imposed identity which had resulted in their exclusion from the Northern region political process and 
structure. The "Middle Belt identity" was identity of convenience, which broke down obviously as a result of mutual suspicion and hate. Furthermore unlike the Hausa-Fulani who were able to form a composite group through the jihad and common language, the middle belt comprised of ethnic groups, which had hitherto existed as independent groups with diverse languages and identities. Though this scenario affirms that identity is fluid and can be reconstructed, it also points to the fact that within any identity there are also other identities which could be mobilized to contest for inclusion, exclusion and/or to create a platform for competition. The ethnic groups obviously suspended their ethnic agenda for a collective identity to contest the superior genetic identity created for the Fulani, which had resulted in domination. Identity construction and reconstruction has become a recurrent trend among these linguistic groups. Linguistic groups that seemly did not exist during the colonial period have emerged and are also contesting for space and public space. Despite these reconstructions the Hausa-Fulani are still the dominant ethnic group in Northern Nigeria and Nigeria at large.

\section{Conclusion}

The colonial creation of a superior racial identity in northern Nigeria has remained an ever present reality in this region of Nigeria and Nigeria at large. The genetic identity which was super imposed on the other ethnic groups played out in terms of dominance in government, civil service and other government agencies. Over the years there have been many agitations at the federal level for increased participation of the other ethnic groups in the political process and structure of the northern region. Some of the agitators have had to adopt a Hausa- Fulani identity to get to such positions. Despite the identity constructions and reconstructions that have taken place and are still taking place in the northern region, the Hausa-Fulani have largely remained dominant in the political process and structure. Hence the "political gene" structure, which the British colonial government endowed the Hausa-Fulani with superior identity, culture and civilization has superimposed Hausa-Fulani dominance over Northern Nigeria social and political structures. The minorities' contests against Hausa-Fulani domination which culminated in the evolving of the UMBC and the creation of minority states in North-Central Nigeria (middle belt) has only exposed the identity, resource and supremacy contests among supposedly Middle-Belt ethnic groups hitherto supposedly united against Hausa-Fulani gene domination. The Hausa-Fulani with the supposed superior gene, linked to Eurasia race remains dominant in the social and political structure of Northern Nigeria.

\section{References}

Alubo, O. (2006) "Ethnic Conflicts and Citizenship Crises in the Central Region”. Ibadan: Spectrum Books. 
Alubo, O. (2004) "Citizenship and Nation Making in Nigeria: new challenges and contestations". Identity culture and politics, CODESRIA, 5(1 and 2).

Azikiwe, B. (1929) Nigerian Political Institutions. The Journal of Negro History, 14(3): 328-340.

Bamshad, M., Wooding, W.S., Watkins, C.T., Ostler, M.A., Batzer \& L.B. Jorde (2003) 'Human Population Genetic Structure and Inference of Group Membership'. American Journal of Human Genetics, 72(3): 578-89.

Berger, P. and Luckmann, T. (1966) "The Social Construction of Reality: a Treatise in the Sociology of Knowledge”. New York: Doubleday and Company.

Best, S. (2006) "The Political Dimensions of Conflicts in the Benue valley". In Timothy and Ajene (Eds.). Conflicts in the Benue valley, Makurdi: University Press.

Billinger, S. (2007) “Another Look At Ethnicity As A Biological Concept: Moving Anthropology Beyond The Race Concept". Critique of Anthropology, 27(1): 5-35.

Bourdon, A. (1904) "The Fulani Emirates of Northern Nigeria". The Geographical Journal, 6: 636-651.

Breton, D. (2004) Genetic Fundamentalism or the Cult of the Gene. Body \& Society, 10: 1.

Brown, K. (1986) "Establishing Difference: Race Ethnicity and the Production of Ideology". Journal of Sociology, 22(2): 175-186.

Orr, C. (1908) The Hausa Race. Journal of the Royal African Society, 7(27): 278-283.

Carter, B. and Dyson, M. (2011) "Territory, Ancestry and Descent". The Politics of Sickle Cell Disease. Sociology, 45(6): 963-976.

Chard, L. (1906) Some Recent Impressions of Northern Nigeria. The Geographical Teacher, 3(5): 191-201.

Condit, M., Parrot, L., Harris, M., Lynch, J. and Dubriwny, T. (2004) "The Role of Genetics in the Popular Understandings of Race in the United States. Public Understandings of Science, 13(10): 249-272.

Dudley, B. (1968) "Parties and Politics in Northern Nigeria". London: Frank Cass and Co LTD.

Duster, T. (2003) "Backdoor to Eugenics". 2nd edition. New York: Routledge.

Duster, T. (2006) 'The Molecular Reinscription of Race: Unanticipated Issues in Biotechnology and Forensic Science'. Patterns of Prejudice, 40(4/5): 427-41.

Gana, A. (2002) 'Federalism and the National Question in Nigeria: A Theoretical Exploration', in Exploration'. In Aaron Gana and Samuel Egwu (Eds.). Federalism in Africa. Framing the National Question. Trenton: Africa World Press. Volume 1.

Hacking, I. (2005) 'Why Race Still Matters'. Daedalus, 134(1): 102-16.

Hambly, D. (1935) Culture Areas of Nigeria. Anthropological Series, 21(3): 367-502. 
Hampshire, K., Smith, R., Malcolm, T. (2001) "Consanguineous Marriages among the Fulani". Human Biology, 73: 597-603.

Hembe, N. (2003) J.S. Tarka: The Dilemma of Ethnic Minority Politics in Nigeria. Makurdi: Aboki Publishers.

Jensen, R. (1969) "Social Class, Race, and Genetics: Implications for Education". Am Educ Research Journal, 5: 1-39.

Maceachern, S. (2007) "Where In Africa Does Africa Start? Identity, genetics and African studies from the Sahara to Darfur". Journal of Social Archaeology, 7: 393-412.

MacEachern, S. (2007) "Where In Africa Does Africa Start? Genetics and African Studies from the Sahara to Dafur". Journal of Social Archaeology, 7(3): 293-412.

Makar, T. (1994) The History of Political Change among the Tiv in the 19th Centuries. Enugu: Fourth Dimension Publishers.

Modood, T., Berthoud, R. \& Nazroo, J. (2002) "Race, Racism and Ethnicity: A Response To Smith". Sociology, 36(2): 419-417.

Moseley, H. (1899) "Regions of the Benue". The Geographical Journal, 14(6): 630-637.

Mu'azzam, I. and Ibrahim, J. (2000) "The Transformation of Regional Identities". Jega (Ed.) Identity Transformation under Structural Adjustment in Nigeria, Nordic African institute, Uppsala.

Mustapha, R. (2006) "Ethnic Structure, Inequality and Governance of the Public Sector in Nigeria. Democracy, Governance and Human Rights". Programme Paper Number 24, United Nations Research Institute for Social Development.

Rosenberg, N.A., Pritchard, J.K., Weber, J.L., Cann, H.M., Kidd, K.K., Zhivotovsky, L.A. et al. (2002) 'Genetic Structure of Human Populations'. Science, (298): 2381-85.

Ruxton, H. (1908) Notes on the Tribes of the Muri Province. Journal of the Royal African Society, 7(28): 374-386.

Santos, V. \& Miao, C. (2004) "Race Genomics and Identity Politics in Contemporary Brazil". Critique of Anthropology, 24: 347-378.

Sarich, V. \& Frank, M. (2004) Race: "The Reality of Human Differences". Boulder, CO: Westview Press.

Schwartz, S. (2001) 'Racial Profiling in Medical Research'. New England Journal of Medicine, 344(18): 1392-93.

Visher, H. (1906) "Journeys In Northern Nigeria”. The Geographical Journal, 28: $368-377$.

Waldsman, R. (1965) "The Fulani Jihad: A Reassessment". The Journal of African History, 6(3): 333-355.

\section{Archival materials}

Charles, O. (1965) the Making of Northern Nigeria. London. Frank Cass and co. Ltd.

CSO/26/ 01505 Munshi Province Annual Reports 1920-1921 
CSO/26/12874 Munshi Province Annual Report 1924

CSO/26/2/ 12874 Munshi Province Annual Report 1925

CSO/26/2/12874 Munshi Province Annual Report 1926

CSO/26/2/12874 Munshi Province Annual Report 1930

CSO/26/2/12874 Munshi Province Annual Report 1931

CSO/26/2/12874 Munshi Province Annual Report 1932

CSO/26/2/12874 Munshi Province Annual Report 1933

CSO/26/2/12874 Munshi Province Annual Report 1934

CSO/26/2/12874 Munshi Province Annual Report 1937

CSO/26/2/12874 Munshi Province Annual Report 1939

CSO/26/2/12874 Munshi Province Annual Report 1943

CSO/26/2/12874 Munshi Province Annual Report 1944

CSO/26/2/12874 Munshi Province Annual Report 1945

CSO/26/2/12874 Munshi Province Annual Report 1946

Meek, C. (1925) Northern Tribes of Nigeria: an Anthropological Account of The Northern Provinces of Nigeria Together with the 1921 Decimal Census. London: Oxford University Press.

Record of Proceedings of the Education Department Conference 1927

Pagan Administration, 1924 